\title{
Coal deposition in carbonate-rich shallow lacustrine systems: the Calaf and Mequinenza sequences (Oligocene, eastern Ebro Basin, NE Spain)
}

\author{
L1. CABRERA \& A. SAEZ \\ Departament d'Estratigrafia i Geologia Histórica, Universitat de Barcelona, Gran Via, 585, 08007 Barcelona, Spain
}

\begin{abstract}
Two main coal-bearing sequences developed during the Oligocene in the Tertiary Ebro Basin, the Calaf (early Oligocene) and Mequinenza (late Oligocene) coal basins. Coal deposition took place in shallow marsh-swamp-lake complexes which sometimes became closed and evolved under warm climatic conditions with fluctuating humidity. These shallow lacustrine systems are closely interrelated with the terminal parts of the distributive fluvial systems which spread from the tectonically active Ebro basin margins. Laterally extensive lignite-bearing sequences, including rather thin, lenticular autochthonous and/or hypautochthonous coal seams with high ash and sulphur contents, characterized coal deposition in the shallow lacustrine systems. Coal seam geometry, which makes them nearly subeconomic, resulted from the tectonic instability during basin margin evolution and the sometimes closed, arid conditions under which the lacustrine systems evolved. High ash and sulphur contents resulted from the inadequate isolation of peat forming environments from clastic influx and from the very low acidity and sometimes high sulphate contents of the lacustrine waters. Coal exploration in shallow lacustrine sequences similar to those described here must take into account that the spread of coal-forming environments and maxima of coal deposition are usually coincident with lake expansions and retraction or shifting of the terminal fluvial zones interrelated with the lacustrine areas.
\end{abstract}

Several coal-bearing sequences developed in Oligocene times in the Tertiary Ebro Basin, NE Spain. The coal seams in these sequences show an almost exclusive relationship with shallow lacustrine palaeoenvironments developed at distal and marginal zones of alluvial fan-fluvial systems.

Despite the fact that these coal deposits are rather thin (up to $0.9 \mathrm{~m}$ thick), and nearly subeconomic, they have been mined since the 19th century in the Calaf and Mequinenza areas (Fig. 1). Most of the mined coal seams are lignites and sub-bituminous coals (dull and bright brown coals). The majority of the seams display rather high ash $(10-35 \%)$ and sulphur contents (1.54-11.88\%) contents and average $5000-6000 \mathrm{kcal} \mathrm{kg}^{-1}$ (on an 'as received' basis CGS 1975; IGME 1975; DGM 1984).

This study is concerned with the relationships between fluvial sequences and shallow lacustrine coal-bearing sequences in the Calaf (early Oligocene) and Mequinenza (late Oligocene) coal basins with emphasis on coals found in shallow lacustrine sequences. Although these Oligocene coals have been mined for a long time, regional depositional models for the coal-bearing sequences do not exist. The objectives of this study are to establish depositional models for the thin seams in the Calaf and Mequinenza areas, in order to provide a guide for future planning of exploration. Moreover, some general inferences will be gathered from the particular characteristics of these case studies.

\section{Tectonic sedimentary and palaeogeographic general setting}

The Oligocene Calaf and Mequinenza coal basins are located in the Eastern Ebro basin (NE Spain, Fig. 1). This basin is the late, intact foreland basin of the Pyrenees. The Catalan Coastal Range to the SE, the Iberian Range to the SW and the Linking Zone between these ranges made up the southern margins of the basin which is asymmetrical in cross-section, with its deeper troughs $(3000-5000 \mathrm{~m})$ located in the northern areas under the southern Pyrenean thrust sheets (Puigdefabregas et al. 1986).

The rising of the Pyrenean thrust belt was probably caused by a limited collision between the Iberian and the European plates, with the Iberian plate being overridden by the European (French) plate (Deramond et al. 1984). Thrust sheet emplacement took place from late Cretaceous to Miocene (Seguret 1970; Muñoz et al. 1986). During this time, predominantly southward nappe emplacements developed, although minor northward-directed thrusting also occurred (Deramond et al. 1984).

The southern margins of the Ebro basin also became tectonically active during its evolution although their activity started later and was relatively minor compared with that of the Pyrenees. However, the tectonic processes along the Palaeogene Catalan Coastal Range strike-slip system (convergent wrenching, limited northward directed upthrusting and cover folding) exerted an important influence on the sedimentary facies distribution (Guimerà 1984; Anadon et al. 1986). The Ebro basin assumed its structural identity during the Oligocene, when the late phases of emplacement of the Pyrenean thrust-sheets took place and tectonic activity spread along the southern margins of the basin.

From the earliest Oligocene to the late Neogene the Ebro basin was an endorheic sedimentary trough and was filled exclusively with non-marine deposits. Large alluvial fan-fluvial systems spread from the tectonically active basin margins, their proximal conglomeratic facies being affected by progressive unconformities (Riba 1976; Anadón et al. 1986). Lacustrine and non-marine evaporitic environments developed in the distal and marginal parts of the widespread alluvial-fluvial systems. Laterally extensive shallow lacustrine sequences, including lignite beds, developed in these environments. The Calaf and Mequinenza lacustrine units 


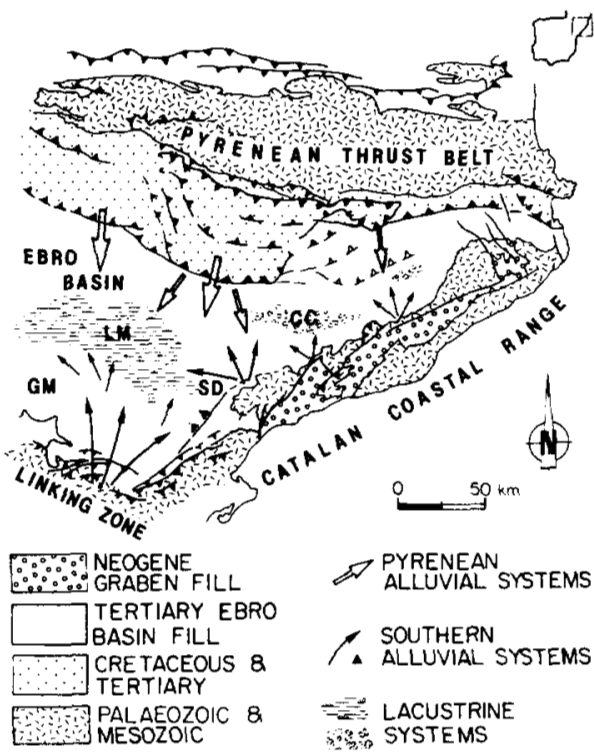

Fig. 1. Location of the Oligocene coal-bearing sequences in the eastern Ebro Basin. The main structural features of the basin margins (after Guimerd 1984 and Puigdefabregas et al. 1986) as well as the distribution of the main depositional systems are broadly shown. Lacustrine systems: CC, Catalan Central System (late Eocene-Oligocene); LM, Los Monegros System (OligoceneMiocene); Fluvial systems: SD, Scala Dei (late Eocene-Oligocene); GM, Guadalope-Matarranya (Oligocene-Miocene); P, Pyrenean (late Eocene to Miocene).

contain the two most important coal-bearing sequences in the Ebro basin.

Quite warm palaeoclimatic conditions existed in the Ebro Basin during the Oligocene. This inference is based on fossil fioras (Fernández Marrón 1973; Depape \& Brice 1963), crocodilia and tortoise remains and palynological data (Sole \& Porta 1982; Cabrera 1983). On the other hand the occurrence in the Oligocene sequences of non-marine evaporites suggests that arid to semi-arid conditions affected the basin during at least part of the Oligocene. Both warm and occasionally dry palaeoclimatic conditions could be linked to the lower palaeolatitude of the Iberian peninsula during the Oligocene (Smith \& Briden 1977) as well as to the isolation of the Ebro basin from the ameliorating influences of the Atlantic ocean and the Tethyan sea.

\section{Methodology}

As mentioned above, the Calaf and Mequinenza coal basins contain rather thin lenticular coal seams. This fact makes it difficult to trace them over long distances. In weathered surfaces, correlation between single coal seams becomes impossible. It has therefore been necessary to investigate the subsurface data available and focus the analysis on the cumulative distribution of coal deposits more than on the trends and patterns of single coal seams.

Both the Calaf and Mequinenza basins have been the subject of exploration surveys concerned with the evaluation of uranium resources (CGS 1975; IGME 1975; DGM 1984). Exploration was mainly carried out using boreholes from which several tens of cores of the subsurface sequences were recovered. Core logs are the main source of subsurface data for establishing the overall trends of facies distribution. Despite coal deposits having been mined for a long time in both basins, there is little available mine data which might supplement the borehole information.

The diverse outcrop conditions in the Calaf and Mequinenza basins have necessarily led to the use of slightly different approaches to the research. The Calaf coal basin is located in a zone of subdued topography. Outcrops of the coal seams and their sequences are rather sparse and small. Accordingly its study has been based heavily on subsurface data complemented by fieldwork in those zones where mapping of facies and measuring of sections were possible (Fig. 4). In the Mequinenza area good, laterally extensive, outcrops occur along the deeply entrenched river valleys and ravines. Subsurface data are not as widely available as in the Calaf Basin, but up to 22 borehole logs have supplemented, to some extent, surface data obtained from mapping and measured sections (Fig. 5).

Stratigraphic frameworks for the coal-bearing sequences were constructed using surface facies maps and measured sections as well as borehole logs. The lithologic logs were correlated using key beds as far as possible. Correlation was also helped by the use of detailed facies maps $(1: 25000)$ by means of which surface and well logs could be correlated with each other.

In each area the coal-bearing sequences were subdivided into several slices with the same thickness. These slices were designated in an ascending order from the base of the studied sequences (Figs 2 and 5). The relatively restricted areal extent of the studied coal-bearing sequences allowed us to assume that the sediments included within each slice were contemporaneous. On the basis of this assumption, limestone, sandstone and coal percentage distribution maps were constructed for each slice. These maps were the basis for the analysis of the evolutionary trends of the coal-bearing sequences and of the coal distribution within them.

\section{Calaf Coal Basin}

\section{General sedimentary framework and palaeoenvironmental conditions}

The Calaf coal-bearing sequence is included in the late Eocene to early Oligocene Catalan Central Lacustrine System (Sáez \& Riba 1986). This system evolved in the central, northeastern Ebro basin area. It shows a close interrelationship with the terminal parts of the distributive fluvial belts which spread from the Pyrenees and the Catalan Coastal Range (Figs 1 and 2). Several lacustrine carbonate and evaporitic depocentres are recorded in the studied sequences where rock thicknesses may attain one kilometre.

From the late Eocene to the early Oligocene the lacustrine depocentres shifted from NE to $\mathrm{SW}$ as a consequence of the tectono-sedimentary evolution of the basin. During the late Eocene the lacustrine sedimentation was strongly influenced by evaporitic conditions (as recorded in the Barbastro and Torà units) and although some carbonate lacustrine sequences developed (Castelltallat unit) the sequences are barren of coal deposits (Fig. 2).

During the earliest Oligocene the main lacustrine depocentre was close to the Calaf area and no evaporitic conditions developed in the sector. The early Oligocene sequence in the Calaf area is essentially terrigenous and was developed in distal alluvial plains, but the upper part of 


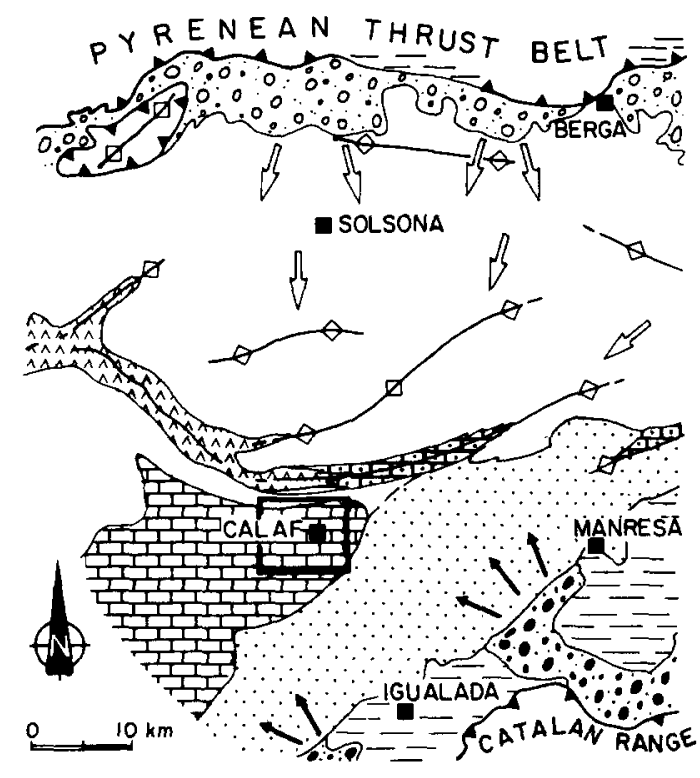

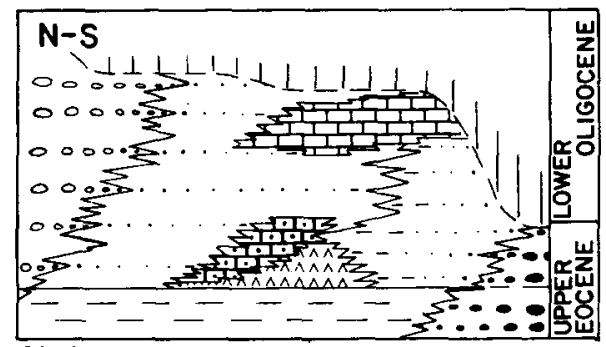

CONGLOMERATES MUDSTONES AND SANDSTONES PROXIMAL TO DISTAL ALLUVIAL-FLUVIAL FACIES

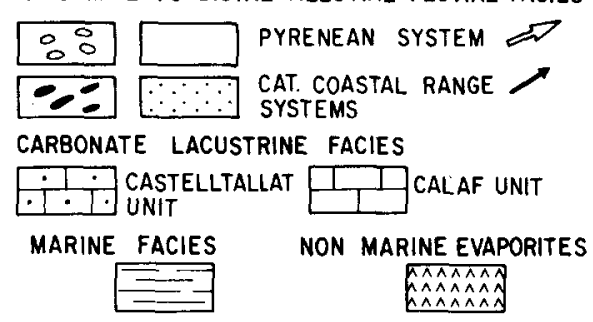

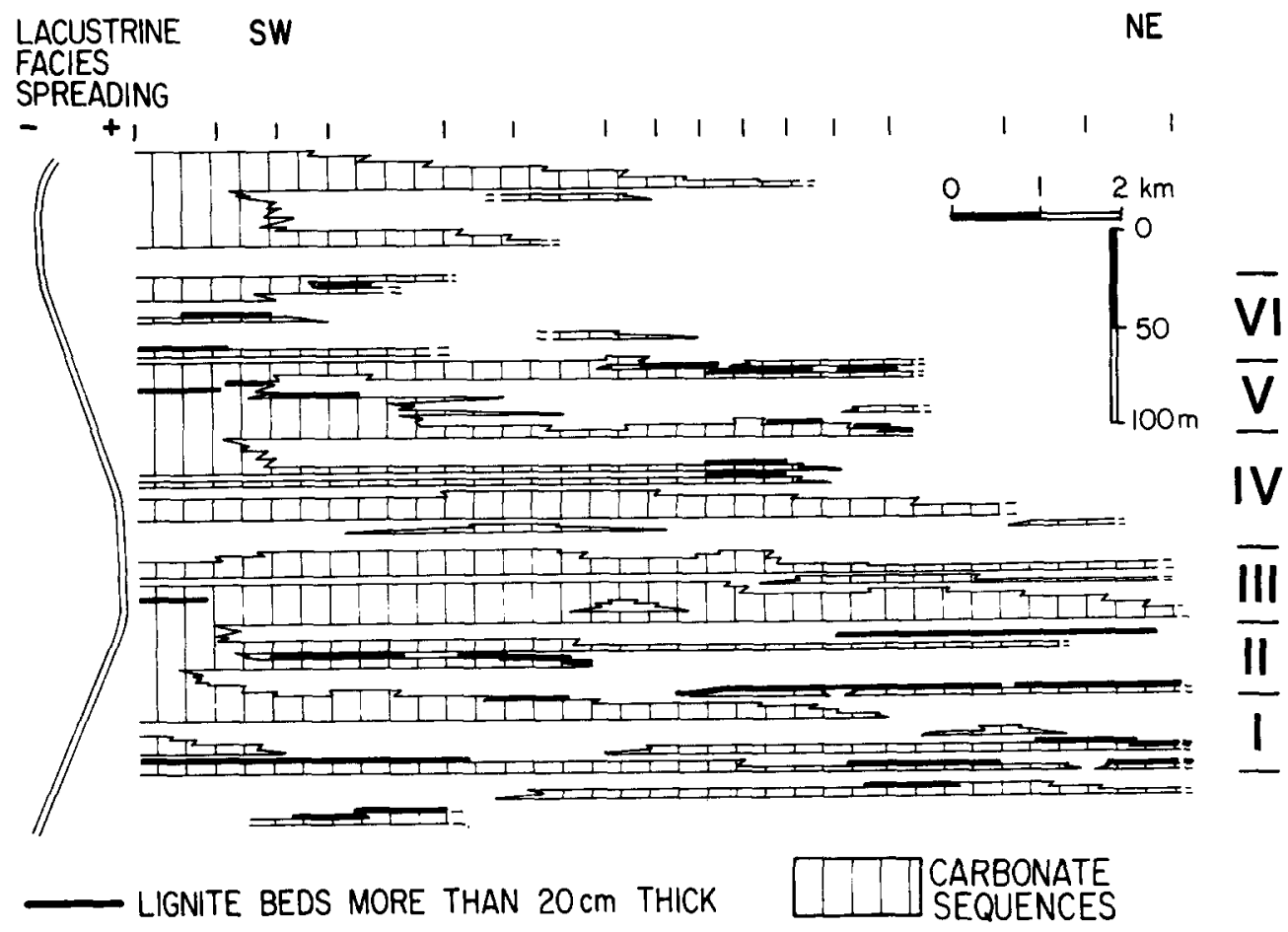

Fig. 2. Geological sketch and stratigraphic framework of the eastern Ebro Basin sectors showing location of the early Oligocene Calaf coal bearing sequences. The cross-section through the coal bearing sequences (square centred on Calaf) shows the interrelationships between the lacustrine and the fluvial dominated sequences as well as the distribution of the main coal seams. the sequence includes a lacustrine-paludine packet which interleaves with coal seams (Calaf unit).

At the end of the early Oligocene, the lacustrine depocentre probably shifted again in a SW direction, giving rise to carbonate lacustrine sequences without noticeable coal deposits (Tàrrega unit).

The carbonate and evaporitic sequences of the Central Catalan Lacustrine System were formed in closed perennial shallow lacustrine complexes and evaporitic mud flats. These environments developed at the distal and marginal zones ahead of the fluvial fringes which spread from the tectonically active Ebro basin margins. The sedimentary and palaeogeographical evolution of the system was influenced by the competitive drainage established from the Pyrenees and from the Catalan Coastal Range (Malsheimer \& Mensink 1979; Allen \& Mange-Rajetzky 1982).

\section{The coal-bearing sequences}

Stratigraphic relationships and lithology. The early Oligocene Calaf coal-bearing lacustrine sequence is up to $400 \mathrm{~m}$ thick. This sequence overlies an alluvial-fluvial 


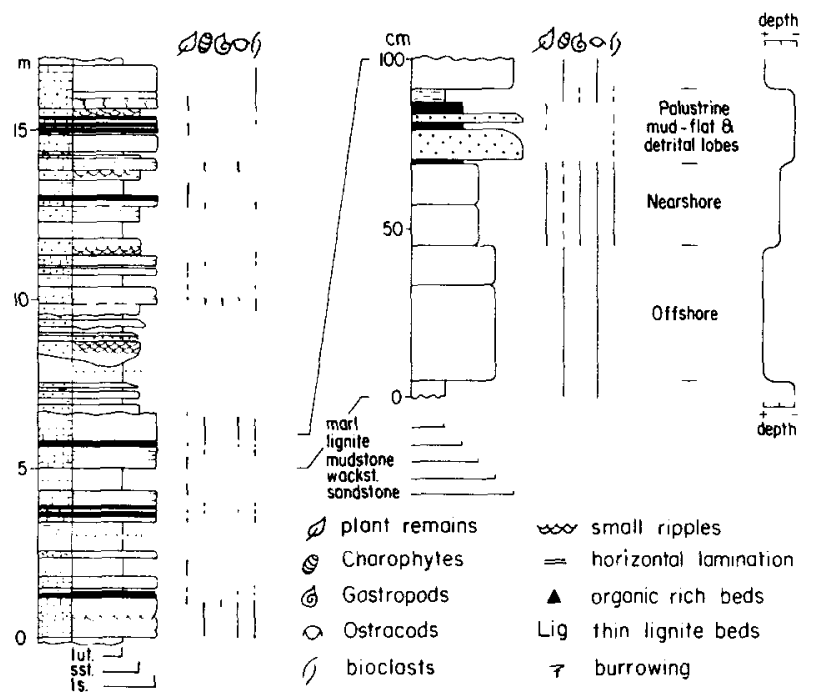

Fig. 3. Sedimentary logs of the lacustrine coal bearing sequences in the Calaf Basin (see text for further explanation).

dominated sequence consisting of red mudstones and channel-fill sandstones up to several metres thick. In the Calaf area the top of the sequence is overlain by red mudstones, while to the SW lacustrine carbonates are still present.

The lacustrine-paludine dominated coal-bearing sequence consists mainly of limestone and grey mudstone beds which are several tens of metres thick and comprise laterally extensive packets (Figs 2 and 3). Minor sandstone and lignite lenses are interbedded in these lacustrine sequences.

Interfingering of the lacustrine-paludine sequences with the fluvial dominated ones results in the gradual thinning of the limestone-mudstone dominated packets, from the inner to the outer zones of the main lake depocentre. An alternation of fluvial sequences with the lacustrine-paludine is recorded around the Calaf lake depocentre (Fig. 2).

Single lacustrine limestone beds are up to $0.5 \mathrm{~m}$ thick but bundles of them several metres thick have been recorded (Fig. 2). Two main carbonate facies can be distinguished on the basis of geometry, colour and bioclastic content. Laterally extensive pale grey charophyte-ostracode mudstones and wackestones are dominant, while lenticular, thin dark grey wackestones and packestones which bear gastropods and minor plant remains occur sporadically (Fig. 3).

Grey, massive mudstone beds range from a few centimetres to some metres in thickness. They are frequently interbedded with thin coal seams ranging from a few centimetres up to $0.8 \mathrm{~m}$, as well as with lenticular channel fill sandstones showing cross bedding and ripple laminations. Minor, thinner more laterally extensive lenticular sandstones are also present (Fig. 3).

Fluvial facies which alternate with the lacustrine sequences consist mainly of red massive mudstones with interbedded channel-fill deposits ranging from 0.2 to $2 \mathrm{~m}$ in thickness.

Palaeoenvironments, sequential trends and palaeontological content. Lacustrine limestones, grey mudstones and coal beds record the sedimentary processes developed in shallow offshore and nearshore lacustrine zones, closely related with marginal-swamp zones. These deposits are usually arranged as sequences up to $1 \mathrm{~m}$ thick, where grey mudstones and coal deposits record the late infilling stages of the shallow lakes and the development of marshes and swamps.

Carbonate sedimentation was often precluded by the terrigenous contributions into the lacustrine-paludine areas. Terminal parts of fluvial lobes developed close to the lakes. Interlobe, paludine mud-flats also developed near the shoreline and offshore shallow lacustrine areas, while subaerial high mud flats were formed ahead of terminal fluvial fringes in the zones not directly related with the lacustrine environments. Minor sandy contributions were fed into the paludine mud-flat areas from the terminal fluvial axes.
Fig. 4. Coal and carbonate isopleth maps showing the evolution of the coal accumulation trends in the Calaf Basin. The overlay of the main sandstone and coal depocentres on the coal and carbonate isopleths emphasizes the evolutionary trends in the basin (see text for further explanation).

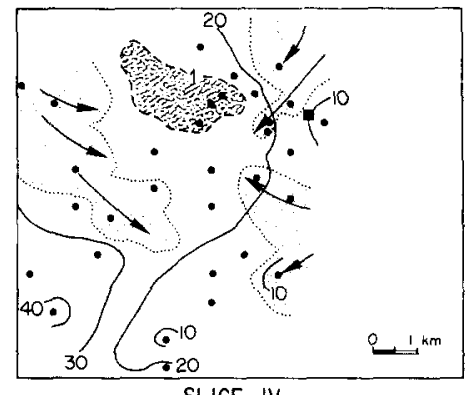

SLICE IV

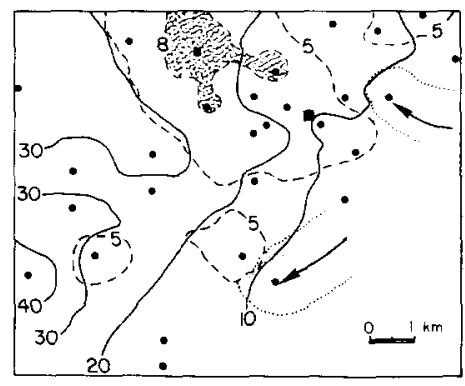

SLICE I

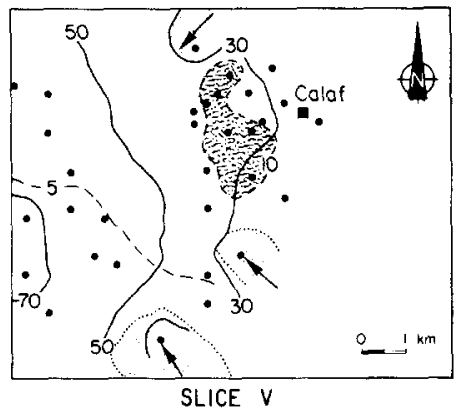

COAL ACCUMULATION TRENDS IN THE CALAF BASIN

$$
\begin{aligned}
& \text { - } 20 \text { Carbonate isopleths } \\
& \text {...-10 Cool isopleths } \\
& \text { - Control points } \\
& \text { - Coal accumulation } \\
& \text { moximo } \\
& \text { Relative maximo of } \\
& \text { sondstone accumulation } \\
& \text { Infersed terrigenous } \\
& \text { contribution trends }
\end{aligned}
$$



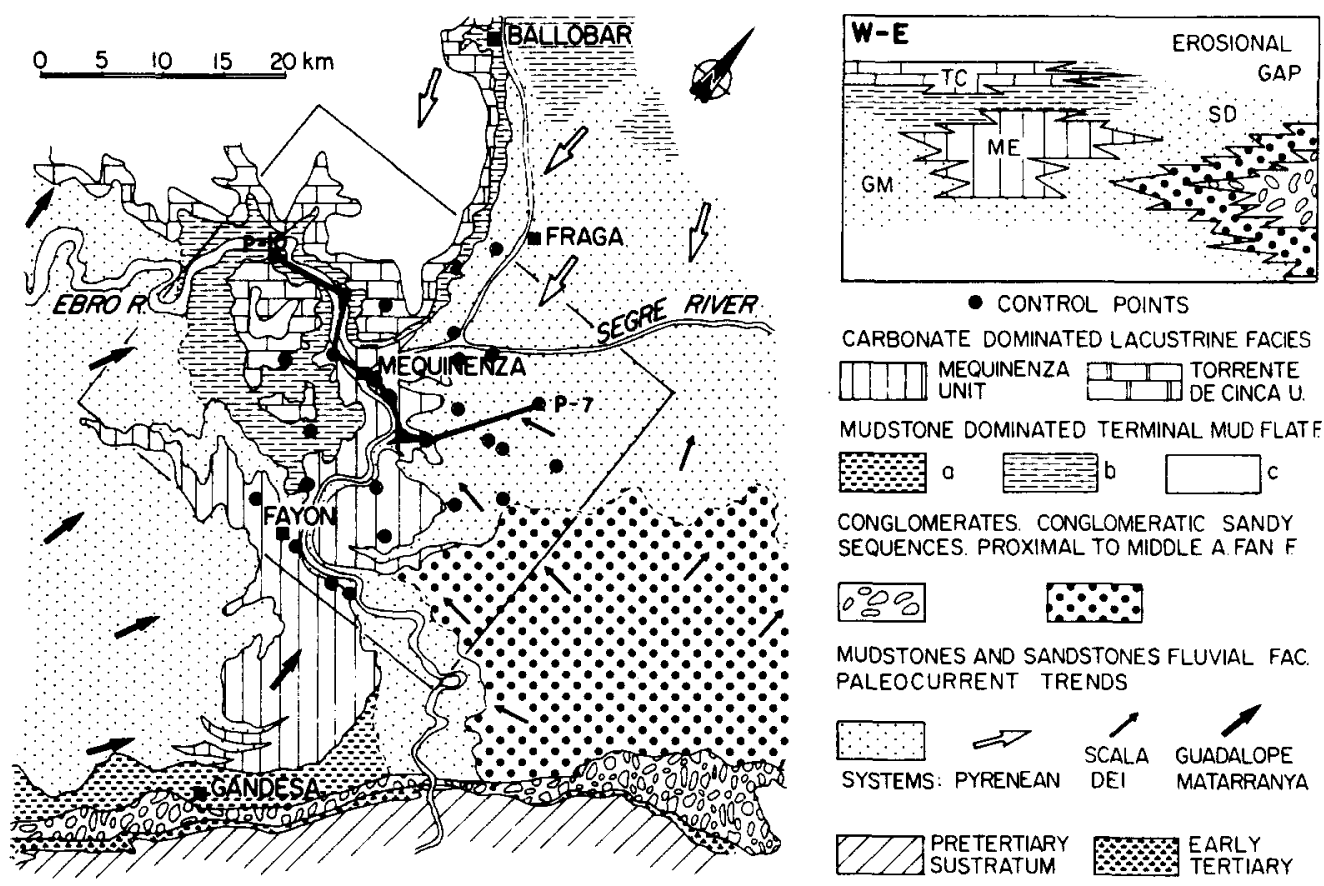

- CONTROL POINTS

CARBONATE DOMINATED LACUSTRINE FACIES DIII MEQUINENZA UIT TORRENTE

MUDSTONE DOMINATED TERMINAL MUD FLATF. \%a a

CONGLOMERATES CONGLOMERATIC SANDY SEQUENCES. PROXIMAL TO MIDDLE A. FAN F

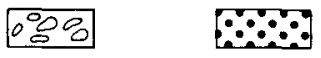

MUOSTONES AND SANDSTONES FLUVIAL FAC. PALEOCURRENT TRENDS
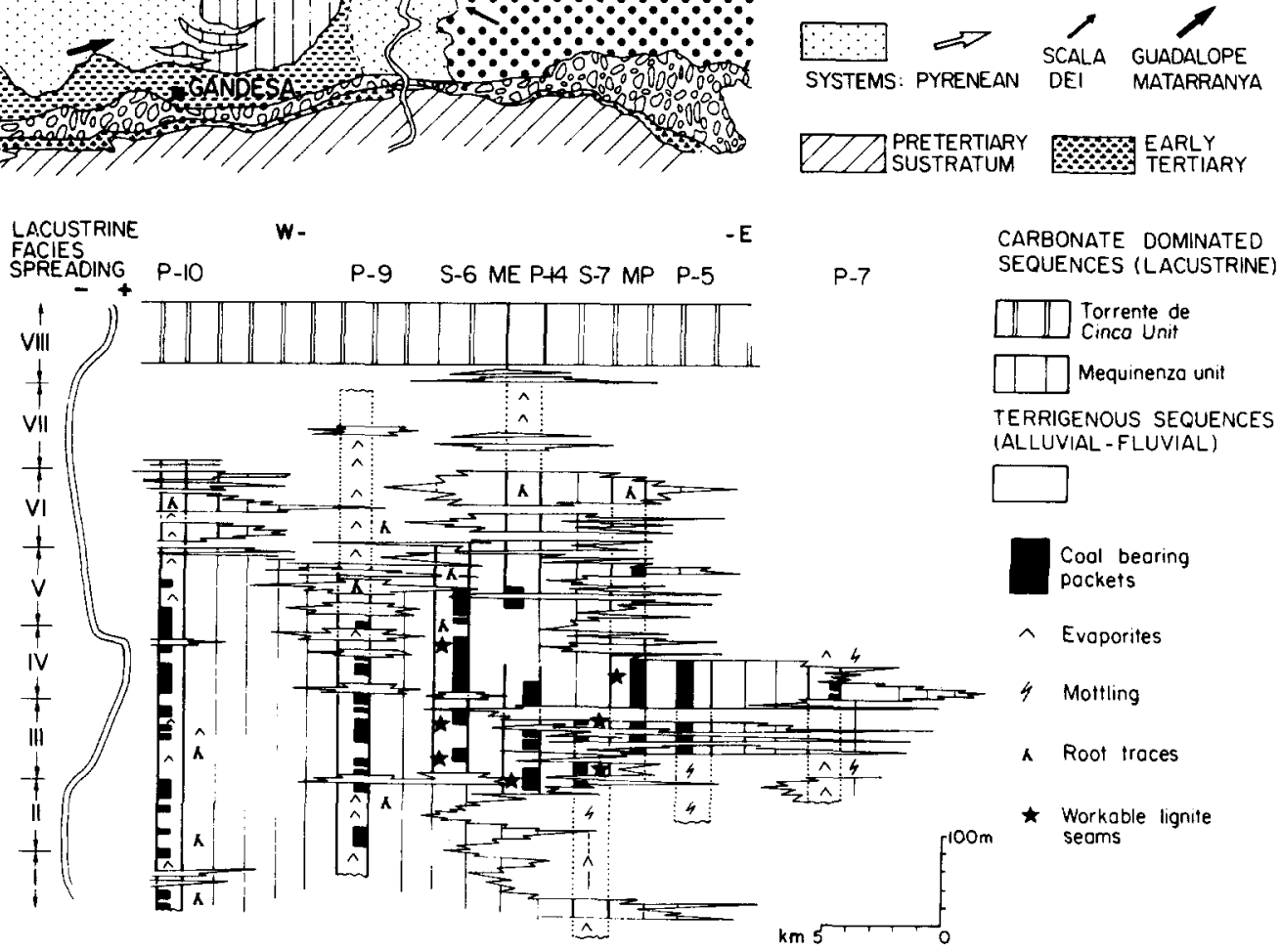

Fig. 5. Geological sketch and stratigraphic framework of the SE Ebro Basin sectors showing location of the late Oligocene Mequinenza coal-bearing sequences. The cross-section through the Mequinenza coal-bearing sequences (see line in the map) shows the interrelationships between the lacustrine, carbonate-dominated units and the fluvial terrigenous dominated facies. The distribution of the coal bearing packets and the main coal seams is recorded, $\mathrm{P}$ and $\mathrm{S}$, borehole logs; ME and MP, measured sections.

The megasequential arrangement of the Calaf coalbearing sequence shows several rapid expansions and contractions of the shallow lakes. As a whole the Calaf coalbearing sequence is a symmetrical megasequence which records successive stages in lake development. The spreading of carbonate-grey mudstone facies records broadly transgressive stages, but the occurrence of repeated shallowing-upwards minor sequences emphasizes the pulsating character of the process. During expansive stages the lacustrine and marsh-swamp environments spread over the terminal alluvial plains, which afterwards re-advanced towards the pre-existing lacustrine areas (Figs 2 and 4). These frequent palaeoenvironmental rearrangements might be linked to changes in terrigenous contributions and/or in water supply.

Palynological remains in the lacustrine-paludine sequences show the occurrence of several forms of 'temperate' tree genera (Carya, Ulmus, Alnus, Salix, Populus) as well as that of thermophyle mesoterms (Sabal, Engelhardtia, Myrica) and megaterms (Sapotaceae). Minor occurrences of 
gymnosperm palynomorphs (Pinus, CupresaceaeTaxodiaceae) and Gramineae are observed (Sole \& Porta 1982). Some of these taxa include forms adapted to dwell in swampy zones (Cupresaceae-Taxodiaceae) while others are clearly hygrophyte (Alnus, Salix, Populus). Although it is not possible to establish their relative importance, it is suggested that a marsh-swamp biotope probably developed around the lacustrine environments. In drier zones extensive grassy plains with wooded areas were present.

\section{Coal deposits: main features, distribution, genesis and accumulation trends}

In the Calaf coal-bearing sequence, coal seams are recorded all through the sequence, although the amount of coal in each slice varies (Figs 2 and 4). Most of the coal seams are related to grey mudstone deposits, but in some cases a close sequential relationship exists with limestones.

Coal deposits consist mainly of lignite to sub-bituminous coal (bright brown coal) with a relatively high calorific value $\left(6400-7042 \mathrm{kcal} \mathrm{kg}^{-1}\right)$ Coal deposits have a very high sulphur content ranging from 2.98 to $8.36 \%$. Moreover, ash content is also noticeable, ranging from 16.46 to $24.18 \%$ (CGS 1975). Clay minerals (kaolinite, illite), quartz, calcite and dolomite are present in the inorganic fraction. Sulphide minerals (mainly pyrite) have been recorded (Martin 1974).

Preliminary petrological studies on the Calaf coal deposits show that they consist mainly of huminite (near $75 \%$ ) with minor amounts of exinite and inertinite. The recorded huminite includes eu-ulminite, telogelinite and eugelinite maceral types. Exinite macerals are represented by crassispores, cutinite and resinite while the inertinite group includes fusinite, semifusinite and sclerotinite with fungal structures (Martin 1974).

The coal-bearing lacustrine sequences in the Calaf area extend for more than $10 \mathrm{~km}$, but the coal seams are only a small part of the sequence. The rather sparse outcrops in the area do not allow lateral continuity to be assumed. Single seams are rather thin, ranging from a few centimetres up to $0.8 \mathrm{~m}$ in thickness and averaging $0.2 \mathrm{~m}$. They show welldefined boundaries and are thinly bedded (Martin 1974).

The mudstone and carbonate facies related to the coal seams are not rich in organic matter. Thin root horizons, a few centimetres thick, have been recorded in some outcrops under the coal seams. Root traces are up to $10 \mathrm{~cm}$ long and just a few millimetres in diameter so they cannot represent large tree roots. Together with the petrological data, this suggests that the Calaf coal seams developed as a consequence of mainly autochthonous and minor hypautochthonous peat deposition in swampy-marshy and shallow ponded areas. Noticeable contributions of woody material could arrive in these areas from the surrounding region. The high ash contents in the coals suggests an influence on the marsh-swamp peat-forming environments of currents generated during flooding episodes.

The distribution of the coal deposits in the Calaf sequences shows they are formed mainly in the transitional zones where subaqueous lake carbonate sedimentation was not dominant. The thickest coal seams are interbedded with grey mudstone beds and are restricted to the nearshore and paludine mud flat facies which developed at the top of the laterally extensive sequences resulting from the successive lacustrine expansions (Figs 2 and 4). On the other hand the distribution of coal seams also suggests changes in the overall trends of peat accumulation. The analysis of coal occurrence in the whole lacustrine unit (Fig. 2) and the coal isopleth maps (Fig. 4) reveal close relationships among the evolutionary stages of the interrelated lacustrine and alluvial-fluvial systems and the coal accumulation trends.

During the phases of progradation of the terminal zones of the Pyrenean fluvial system, recorded by relatively high percentages of sandstone deposits, peat-forming areas were severely restricted and coal accumulation almost totally precluded (Fig. 4, slice IV). Larger percentages of coal accumulation and wider areal extent of the peat-forming environments are recorded during stages of moderate persistence of the lacustrine environments in the area (up to $40 \%$ of lacustrine limestones recorded in the SW sector) combined with a retrogradation of the fluvial axes (Fig. 4, slice I). When retrogradation of the fluvial axes was coincident with a high persistence of the lacustrine environments in the area (up to 70\% of lacustrine limestones located in the SW sector) the largest amounts of coal accumulated in the paludine mud-flat, relatively sheltered from terrigenous contributions (Fig. 4, slice V). This would have resulted from the high level and relative stability of the water-table linked to the lake.

\section{Mequinenza coal basin}

\section{General sedimentary framework and palaeoenvironmental conditions}

The Mequinenza coal bearing sequence is included in the Los Monegros Lacustrine System (Cabrera 1983; Cabrera et al. 1985). This is a complex of carbonate dominated lake sediments which developed in the SE Ebro basin during the late evolutionary stage of the Pyrennean southern foreland basin. All through late Oligocene until earliest Miocene times, shallow lacustrine limestones and mudstones and minor sandstones, coal and evaporite deposits were formed in the inner parts of this basin. These deposits form sequences up to $700 \mathrm{~m}$ thick which pass laterally into fluvial facies. Subsurface wells have recorded the existence of several carbonate lacustrine depocentres which extend from the study area to the west, displaying similar stratigraphic relationships with the fluvial sequences. Fluvial sequences which interfinger with inner lake deposits record the influence exerted on the lake areas by several alluvial fan-fluvial systems (Colombo 1980; Cabrera 1983; Allen et al. 1983; Cabrera et al. 1985). The Guadalope-Matarranya and the Scala Dei Systems spread from the Iberian Range-Linking zone margins and from the Catalan Coastal Range respectively (Figs 1 and 5). Persistent influence was also exerted by the southward prograding Pyrenean fluvial systems (Fig. 1).

The Los Monegros lacustrine system was a closed large, perennial to semiperennial, shallow, swamp-lake complex which underwent repeated changes from fresh to slightly saline water conditions. Sedimentological and palaeontological data suggest that the system evolved under arid to semi-arid conditions which caused noticeable expansions and contractions. During contraction the lake waters became saline, and evaporitic facies developed. The late evolutionary stages of the whole lake system were ruled by drier conditions which gave rise to a more widespread development of evaporitic playa lakes (Cabrera 1983; Cabrera et al. 1985). 
The coal-bearing sequence

Stratigraphic relationships and lithology. The late Oligocene sequence in the Mequinenza area includes a thick shallow lacustrine carbonate unit with a maximum recorded thickness of nearly $500 \mathrm{~m}$ (Mequinenza unit, Fig. 5). This carbonate-dominated unit overlies thick alluvial-fluvial sequences consisting of channel sandstones, flood-plain and terminal mud-flat mudstones. It is overlain in turn by an alluvial sequence which consists mainly of red and mottled mudstones with interbedded thin channel fill and sheet sandstones as well as minor limestone and nodular anhydrite beds. Lateral changes from the carbonate-dominated sequences into the fluvial terrigenous dominated sequences are recorded throughout the Mequinenza unit. The whole Oligocene sequence in the area is covered by an upper lacustrine carbonate unit (Torrente de Cinca unit, Fig. 5).

The Mequinenza coal-bearing unit consists mainly of pale brown to grey micritic limestones, grey mudstones and minor sandstone lenses and sheets. Thin lenticular coal seams are recorded in the lower and middle parts of the unit. Limestone beds usually range from 0.1 to $0.5 \mathrm{~m}$ in thickness but they can attain $1.5 \mathrm{~m}$. Limestone beds can be several tens of metres thick in the inner parts of the carbonate depocentre but they thin towards the alluvialfluvial sequences.

Mudstone deposits range from thin laminae interbedded in the carbonate-dominated packets to beds several metres thick which interleave with trough and planar cross bedded sandstones. Individual sandstone lithosomes include lenticular channel fills and more laterally extensive lenses. The thickness of the channel fill deposits ranges from a few decimetres up to several metres. They become thicker away from the limestone dominated sequences.

Minor lenticular gypsum and nodular anhydrite deposits are recorded in the carbonate dominated lacustrine sequences. Despite the fact that these early diagenetic evaporite deposits are not large, they show a wide stratigraphic range in some of the borehole logs (see P-9 and P-10 borehole logs, Fig. 5).

Palaeoenvironments, sequential trends and palaeontological content. The distribution of the areas of carbonate sedimentation was controlled by terrigenous contributions to the shallow lakes. Small scale delta and larger interdeltaic plains, where mudstone and sandstone sequences developed, occurred in the marginal lake areas. Subaerial evaporitic mud-flats also developed ahead of the terminal fluvial fringes in zones not closely related with the lake shores (Cabrera 1983; Cabrera et al. 1985).

Marginal nearshore and shallow offshore lacustrine carbonate deposits, with interbedded minor mudstone, sandstone and coal deposits, developed in the lake zones which were more isolated from active fluvial systems. Paludine carbonate marshes and/or swamps and evaporitic carbonate flats developed in the outer lacustrine fringes at times of lowered water level.

The sequential arrangement of the Mequinenza coal bearing sequences records diverse stages of progradation, retrogradation and lateral shifting of the terminal fluvial lobes which spread from the tectonically active southern basin margins (Fig. 5). Moreover, the diverse spreading and occurrence of emersion features in the lake sequences reflect the development of lacustrine transgressions and regres- sions. Carbonate swamp-marsh paludine facies and evaporitic carbonate flats spread considerably during the retractive phases.

Very widespread charophyte, gastropod and ostracode fossil assemblages have been recorded in the limestone and mudstone facies. These assemblages become more restricted in the fluvial-dominated sequences where several fossil mammal assemblages have been recorded (Cabrera 1983; Agusti et al. 1984). The palynological record is rather sparse (Solé, in Cabrera 1983) but it charts the development of widespread marsh and swamp fringes around the lacustrine areas. In drier zones not directly related with the lacustrine areas, grassy, savana-like plains including patches of wooded areas, were probably the main biotopes where vegetation developed. Ferns, temperate hygrophytes (Alnus, Salix, Populus) and hydrophytes (Typha) would dwell around and close to the lake areas. Halophytes (Chenopodiaceae-Amaranthaceae) would develop especially in the evaporitic environments while woody xerophytic elements (Pinus, Ceratonia, Cistus, Phillyrea) and thermophyle mesoterm ones (Myrica, Engelhardtia) made up the subordinate wooded areas.

\section{The coal deposits: distribution, main features, genesis and accumulation trends}

In the Mequinenza coal basin, coal deposits are restricted to the lower and middle parts of the Mequinenza lacustrine unit. The upper part of the unit consists mainly of carbonate swamp-marsh paludine facies sequences. These display very widespread, well developed subaerial features (root traces, pseudo-microkarst, paludine brecciation) and are barren of coal (Cabrera 1983). On the other hand, the lower and middle parts of the lacustrine sequences contain several coal-bearing packets which alternate with barren deposits. Most of coal seams are closely related to lake limestones or marly limestones and less commonly to mudstone and sandstone facies.

Coal deposits consist mainly of lignite to sub-bituminous coal (dull-bright brown coal with a moderate calorific value $\left(3500-5500 \mathrm{cal} \mathrm{kg}^{-1}\right)$. They have a rather high ash content (from 10 to $65 \%$, averaging $30-35 \%$ on an as-received basis) and are frequently true carbominerites (Stach et al. 1982). They also have very high sulphur contents (from 1.54 to $11.88 \%$, averaging $3-8 \%$ on as-received basis, IGME 1975).

Although the coal-bearing sequences extend for several kilometres, coal seams are not laterally persistent and they are frequently seen to thin and split in outcrops, open pits and mines. Single coal seams are often rather thin with sharp, well-defined boundaries. They range from a few centimetres up to $0.9 \mathrm{~m}$ in thickness, averaging less than $20-40 \mathrm{~cm}$. The single, lenticular seams can be traced over short distances (from several hundred metres up to about $1 \mathrm{~km}$ ). Bundles of thin coal seams alternating with limestones and marly limestones, make up laterally extensive sequences up to a few metres thick which can be traced over greater distances. The thickest coal seams usually interbed with thin limestone lenses and layers.

Some small-scale sequential trends of organic debris accumulation have been recorded. Thin carbonate beds including laminae consisting of reworked organic debris are succeeded by lignite beds a few centimetres thick and, finally, by a lignite seam several decimetres thick (see Fig. 
$6 \mathrm{~B}, 1.5-2.2 \mathrm{~m}$ ). The carbonate and mudstone facies closely related with the coal seams often show, besides the very thin organic-rich laminae, a great deal of reworked plant macrorests. Moreover, the thinner coal beds often display a well developed lamination, bioclastic laminae of subaqueous gastropod shells (Planorbidae) and even articulated fish skeletons. Most of these features have also been recorded in the thicker coal seams which show organic-rich thin bioclastic mudstone partings up to a few millimetres thick. In these thicker seams laminated coal facies alternate with others of more massive appearance.

Most of the above-mentioned features and other less positive evidence (absence of stump or stem horizons and no record of seat-earths or rooted horizons linked to the coal seams) suggest that some of the thicker coal seams result from the reworking of plant remains from swampy-marshy zones into subaqueous, nearshore to offshore lacustrine areas. Peat deposition could take place under the influence of small scale turbid underflows and/or geostrophic flows generated by river inflows and/or storms. These currents would rearrange and distribute vegetal debris from the swampy-marshy areas into the closely related, nearby shallow lake zones, forming hypautochthonous coal deposits, with a rather high ash content.

However, subaqueous autochthonous peat deposition can also take place in reed swamps fringing lacustrine areas. It is possible that some of the coal seams may have developed in this environment, with a minor rearrangement of reed debris combined with external plant debris brought in by the above mentioned currents, generated in the deltaic and interdeltaic zones.

The distribution of the coal deposits in the Mequinenza lacustrine unit, where fluvial marginal lacustrine and inner lacustrine facies alternate (Fig. 5), clearly records that they developed within nearshore and offshore zones, either with low terrigenous contributions and high water-table or in subaqueous conditions. The distribution of coal seams in the Mequinenza unit also records a long term evolutionary trend in the lake system. The analysis of the stratigraphic framework of the unit (Fig. 5) and the isopleth maps (Fig. 7) reveals a direct relationship between the evolutionary stages of the lake system and the coal accumulation trends. During regressive stages (slices III and V, Figs 5 and 7) offshore lake areas were restricted. Alluvial facies derived from the tectonically active basin margins impinged on the central basin areas. The distribution of coal accumulation percentages indicates that coal deposition was often confined to a rather limited area. On the other hand, during transgressive stages (slice IV Figs 5 and 7) subaqueous lacustrine environments spread noticeably. Larger amounts of coal were deposited over a wider area, so that thicker and more laterally persistent coal-bearing packets developed during this stage.

Compared with slice IV, the slice $V$ map reflects a reduction of the area occupied by lake and marsh-swamp facies. Greater terrigenous influences are also recorded
Fig. 6. Sedimentary logs of the lacustrine coal bearing sequences in the Mequinenza Basin. Note in $\log B$ ( 4 to $12 \mathrm{~m}$ ) occurrence of some well defined small scale sequential trends of plant debris accumulation (see text for further explanation).

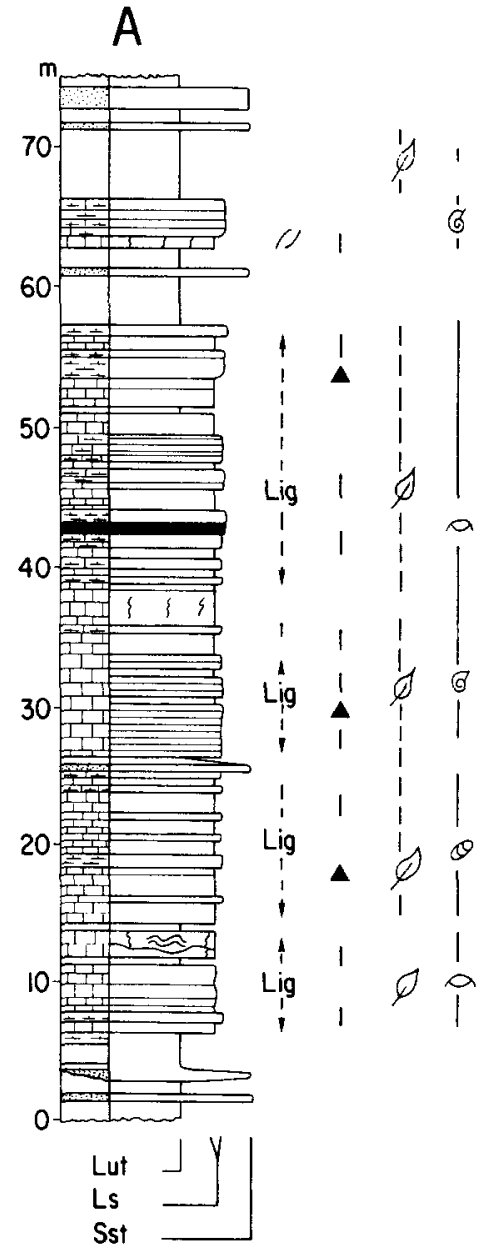




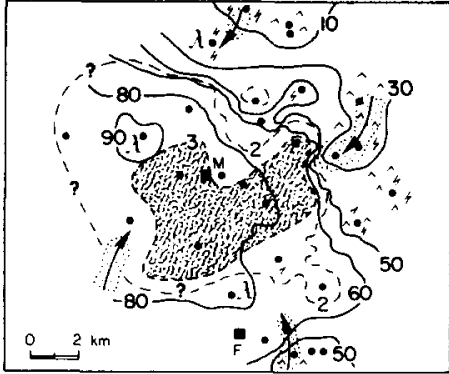

SLICE IV

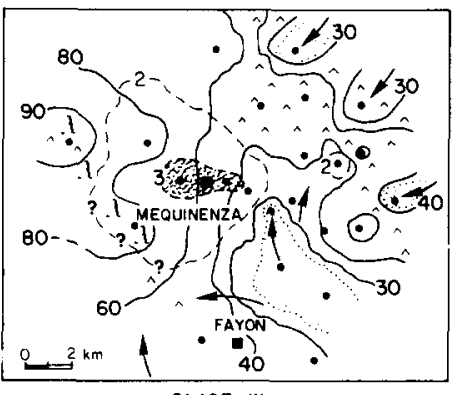

SLICE III

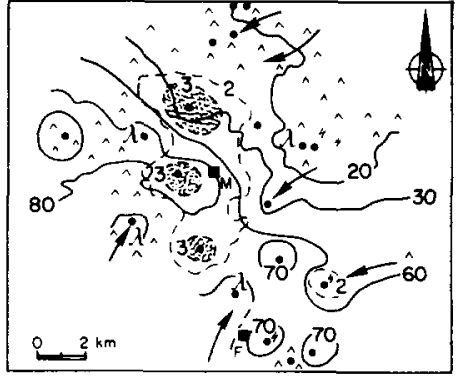

SLICE $V$

COAL ACCUMULATION TRENDS IN THE MEQUINENZA BASIN

$\hat{\wedge}$ Evaporitic focies

1 Polustrine brecciated facies

4 Mottling

See legend in Fig. 4
Fig. 7. Coal and carbonate isopleth maps showing the evolution of the coal accumulation trends in the Mequinenza Basin. The main sandstone and coal depocentres as well the distribution of the subaerially influenced facies (evaporitic and palustrine) are overlain on the coal and carbonate isopleths in order to emphasize the basin evolutionary trends (see text for further explanation). although sandstone contributions were severely reduced (Fig. 7). This restrictive trend becomes more evident in the next evolutionary stage (slice VI, Fig. 5) during which coal deposition was totally precluded, the areal extent of the carbonate deposits became severely restricted and paludine carbonate deposits with well developed subaerial diagenetic, features dominated.

\section{Discussion and concluding remarks}

Lacustrine systems and closely related marsh-swamp areas are potentially suitable settings for thick coal deposits to develop (Falini 1965; Hacquebard \& Donaldson 1969; Teichmüller \& Teichmüller 1982; Bustin et al. 1985). Most of the known case studies refer to limnic coals developed in lakes and/or swamps related to alluvial fans (Heward 1978), fluvial systems (Etheridge et al. 1981; Flores 1981; Gersib \& McCabe 1981; Flores \& Hanley 1984; Nurkownski \& Rahmani 1984) and/or lake delta systems (Surdam \& Wolfbauer 1975; Ryder et al. 1976; Ayers \& Kaiser 1984; Li Sitian et al. 1984). Most of the limnic coal basins which contain thick, workable coal seams, resulted from persistent local subsidence in fault bounded settings (see for instance Heward 1978; Wehmeyer et al. 1986; Whateley 1986). Coal deposits in other lake basins are in general thin and uneconomic, although in some cases they can be important source-rocks for both oil and gas (Rahmani \& Flores 1984).

The development of the Oligocene Calaf and Mequinenza coal-bearing sequences took place during the late evolutionary phases of the eastern and central sectors of the Ebro Basin, the southern foreland basin of the Pyrenees. Although foreland tectonic settings are potentially suitable for the development of coal-bearing sequences (Teichmüller \& Teichmüller 1982; Galloway \& Hobday 1983), other factors prevented the development of very extensive, thick coal seams in the Oligocene sequences studied. Both tectonosedimentary and climatic factors affected coal deposition and preservation.
Tectonic activity along the Ebro basin margins caused a complex evolution of the fringing alluvial-fluvial systems. Frequent progradation, retrogradation and shifting of the middle and terminal parts of the fluvial fringes prevented the steady development of large, sheltered marginal (interlobe) and/or distal zones where stable coal-forming environments could develop (Fig. 4, slice IV; Fig. 7 slices III and V). Retreat or shifting of the fluvial active zones allowed lacustrine-swampy, peat-forming environments to develop (Fig. 4, slice V; Fig. 7, slice IV).

High and constant groundwater table is one of the most important factors controlling peat accumulation (Teichmüller \& Teichmüller 1982; Galloway \& Hobday 1983; Bustin et al. 1985). Because of the endorheic character of the inland shallow lacustrine systems developed in the Ebro Basin, the delicate equilibrium between subsidence, aggradation and water table level is unlikely to have been kept in balance for very long time spans. Moreover, if the climate was arid to semiarid (as it was for most of late Oligocene time), the regional groundwater table would be rather low and fluctuating. These features restricted the development of the potential coal-forming environments to inner and central parts of the basin, especially during dry periods.

Both the rapidly evolving terminal fluvial zones and the fluctuating water table conditions precluded the development of thick and laterally extensive coal seams. In broad outline, the areal extent and distribution of the peat forming environments altered constantly in a relatively short time span because of the frequent changes in the distribution of environments. The main stages of coal deposition took place in expansive phases of the shallow lakes both in the Calaf and Mequinenza basins (Fig. 4, slice V; Fig. 7, slice IV). These expansions gave rise to the spreading, or development, of relatively stable subaqueous shallow lacustrine and marsh-swamp peat-forming environments and as a consequence, larger amounts of coal and thicker coal seams developed. 

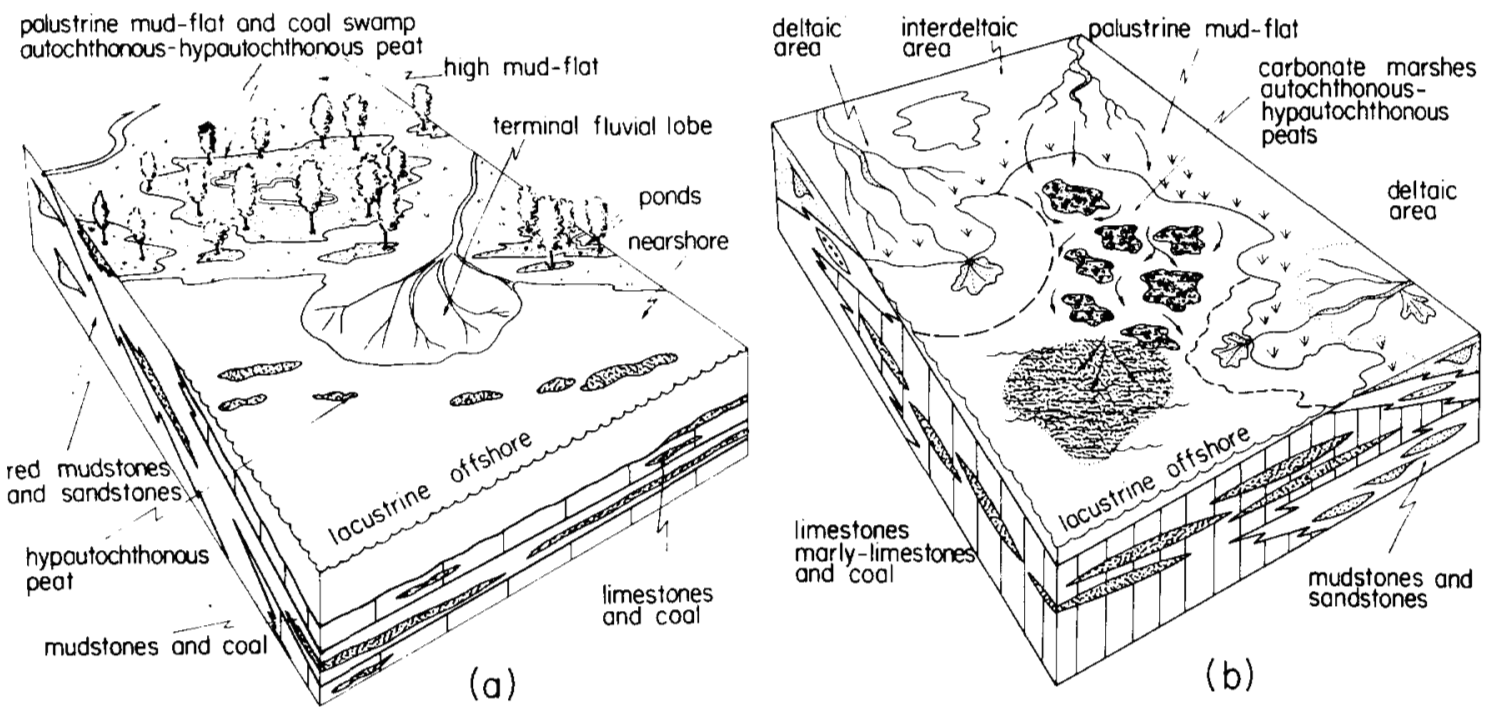

Fig. 8. Lacustrine general models for the development of coal deposits in the Calaf (a) and Mequinenza (b) coal basins during lake expansive stages (see text for explanation).

Apart from the geometric features of the coal seams, the quality of coals was also strongly influenced by the environmental conditions under which the peats developed. Calaf coal deposits developed mainly in the marginal areas of shallow lakes and were strongly influenced by the evolution of terminal-fluvial lobes (Fig. 8). The Mequinenza coal-bearing sequence was also closely related to the terminal parts of fluvial fringes and even the origin of most of the coal seams appears to be linked to the activity of river inflow generated currents. In both the Calaf and Mequinenza basins the areas where peat accumulated were not isolated from clastic influx and, as a result, high ash impure coals developed.

The high sulphur contents recorded in the coals exceed the average values usually accepted for high quality coals. These high values resulted directly from the depositional conditions. Preservation of gastropod shells in the coal seams (as in the Mequinenza basin) and the close relationships between coals and carbonate facies in both coal basins, suggest that water acidity was very low. Moreover, sulphate content in lake waters would rise noticeably as a result of evaporation during the shrinkage of the lake under especially dry conditions (Mequinenza Basin). Both low acidity and high sulphate content in water heavily enhances sulphur bacteria activity and gives rise to very high sulphur content peats with extreme decomposition of the plant remains (Teichmüller \& Teichmüller 1982).

Thus the endorheic basin conditions and the rapid tectonosedimentary evolution of the basin resulted in the environmental instability which prevented the development of thick coal seams in the shallow lacustrine-marshy sequences and totally precluded the development of coalbearing fluvial sequences, especially during dry periods. The kind of depositional environment and the evolution of the systems were the most important factors in determining coal seam geometry and coal quality.

The results of the analysis of facies relationships and sequential trends in the studied coal basins can be helpful when applied to new exploration projects in similar settings elsewhere. In the Calaf basin coal deposits formed in swampy-marshy interlobe zones whose water table level was closely related to a nearby shallow lake which evolved under warm, moist climatic conditions (Fig. 8a). Coal deposits will usually be located in intermediate zones between alluvial dominated and lacustrine dominated sequences (Fig. 4). Thus, borehole exploration must take into account the possible existence of several coal depocentres of moderate areal extent and separated from each other by terrigenous dominated sequences barren of coal, formed in the active alluvial systems.

In the Mequinenza basin, coal deposits formed in shallow lake and marshy zones which evolved under closed arid to semiarid conditions. Coal deposits will usually be located in the inner parts of the lake system and will be rare in the fringing alluvial-fluvial sequences (Fig. 8b). Exploration must be developed by putting boreholes in the inner shallow lacustrine sequences, taking into account the possible existence of several coal depocentres (Fig. 7).

We gratefully acknowledge the revision of the manuscript and suggestions for improvements made by P. A. Allen, P. Friend and L. Frostick. The study of the Mequinenza Basin cores was made possible by the support and cooperation of the Servei Geològic de la Generalitat de Catalunya. Ll. Cabrera has benefitted from the financial support of the CIRIT of the Generalitat de Catalunya.

\section{References}

Agusti, J., Anadon, P., Arbiol, S. \& Cabrera, Ll. 1984. Biozonación mediante roedores (Mammalia) del tránsito Oligoceno-Mioceno en el sector Sureste de la Cuenca del Ebro. Paleontologia $i$ evolució, 17, $131-60$.

Allen, P. A. \& Mange-Rajetzky, M. 1982. Sediment dispersal and palaeohydraulics of Oligocene rivers in the eastem Ebro Basin. Sedimentology, 29, 705-16.

- Cabrera, Ll., Colombo, F. \& Matter, A. 1983. Variations in fluvial style on the Eocene-Oligocene alluvial fan of the Scala Dei Group, SE Ebro Basin, Spain. Journal of the Geological Society, London, 140, $133-46$.

anadon, P., Cabrera, Ll., Colombo, F., Marzo, M. \& Riba, O. 1986. Syntectonic intradeformational unconformities in alluvial fan deposits, Eastern Ebro Basin margins (NE Spain). In: Allen, P. A. \& Homewood, P. (eds) Foreland Basins. Special Publication of the International Association of Sedimentologists, 8, 33-45. 
- - Guimera, J. \& Santanach, P. 1986. Paleogene strike-slip deformation and sedimentation along the southeastern margin of the Ebro Basin. In: BIDdLe, K. \& Christie-Blick, N. (eds) Strike-Slip Deformation, Basin Formation and Sedimentation. Special Publication of the Society of Economic Palaeontologists and Mineralogists, 37, 303-18.

AYERS, W. \& KAISER, W. 1984. Lacustrine-interdeltaic coal in the Fort Union Formation (Palaeocene), Powder River Basin, Wyoming and Montana, USA. In: RaHMANI, R. \& Flores, R. (eds) Sedimentology of Coal and Coal-bearing Sequences. Special Publication of the International Association of Sedimentologists, 7, 61-84.

Bustin, R., Cameron, A., Grieve, D. \& Kalkreuth, W. 1985. Coal Petrology. Its Principles, Methods and Applications. Geological Association of Canada. Short Course Notes, 3, 2nd Edn.

CABRERA, Ll. 1983. Estratigrafia y sedimentología de las formaciones lacustres del tránsito Oligoceno-Mioceno del SE de la Cuenca del Ebro. PhD thesis, University of Barcelona.

- Colombo, F. \& Robles, S. 1985. Sedimentation and tectonics interrelationships in the Paleogene marginal alluvial systems of the SE Ebro Basin. Transition from alluvial to shallow lacustrine environments. In: Rosell, J. \& Mila, M. (eds) Excursion Guide Book of the 6th European Regional IAS Meeting. Excursion 10, 393-492.

CGS 1975. Estudio geologico-minero del área lignitifera y uraniffera de Calaf.

Colombo, F. 1980. Estratigrafia y sedimentología del Terciario inferior continental de los Catalánides. PhD thesis. University of Barcelona.

DePaPe, G. \& BRICE, D. 1965. La flore oligocène de Cervera (Catalogne). Annuaire Société Géologique Nor. 85, 111-18.

Deramond, J., Fisher, R., Hossack, J., Labaume, P., Seguret, M., Soula, J. C., Viallard, P. \& Williams, G. 1984. Structural Geology of the Central Pyrenees. Field Guide of Conference trip to the Pyrenees. Paul Sabatier University. Toulouse, France.

DGM 1984. Investigación de lignitos en el área de Mequinenza (Zaragoza-Huesca-Lérida). Plan energético nacional.

ETHRIDGe, F., JACKSON, T. \& YounberG, A. 1981. Floodbasin sequence of a fine-grained meander belt subsystem: the coal-bearing lower Wasatch and Upper Fort Union Formations, southern Powder River basin, Wyoming. In: ETHRIDGE, F. \& FlORES, R. (eds) Recent and Ancient Non-marine Depositional Environments: Models for Exploration. Special Publication of the Society of Economic Palaeontologists and Mineralogists, 31, 95-108.

FalinI, F. 1965. On the formation of coal deposits of lacustrine origin. Geological Society of America Bulletin, 76, 1317-46.

Fernandez MarRon, M. 1973. Reconstrucción del paleoclima del yacimiento oligocénico de Sarreal (Tarragona), a través del estudio morfologico de los restos foliares. Boletin Sociedad Española História Natural, 71, $237-42$.

FLoRES, R. 1981. Coal deposition in fluvial paleoenvironments of the Paleocene Tongue River Member of the Fort Union Formation, Powder River basin, Wyoming and Montana. In: ETHERIdGe, F. \& Flores, R. (eds) Recent and Ancient Non-marine Depositional Environments: Models for Exploration. Special Publication of the Society of Economic Palaeontologists and Mineralogists, 31, 169-90.

— \& HANLEY, J. 1984. Anastomosed and associated coal-bearing fluvial deposits: Upper Tongue Member, Palaeocene Fort Union Formation, northern Power River Basin, Wyoming, USA. In: RAHMANI, R. \& Flores, R. (eds) Sedimentology of Coal and Coal-Bearing Sequences. Special Publication of the International Association of Sedimentologists, 7, 85-103.

Galloway, W. \& Hobday, D. 1983. Terrigenous Clastic Depositional Systems. Springer Verlag, New York.

GersiB, G. \& MCCABE, P. 1981. Continental coal-bearing sediments of the Fort Hood Formation (Carboniferous), Cape Linzee, Nova Scotia, Canada. In: ETHRIdGe, F, \& Flores, R. (eds) Recent and Ancient Non-Marine Depositional Environments: Models for Exploration. Special Publication of the Society of Economic Palaeontologists and Mineralogists, 31, 95-108.

GuIMERA, J. 1984. Paleogene evolution of deformation in the northeastern Iberian Peninsula. Geological Magazine, 121, 413-20.

HacquebarD, P. \& Donaldson, J. 1969. Carboniferous coal deposition associated with flood-plain and limnic environments in Nova Scotia. In: DAPPles, E. \& HopkINs, M. (eds) Environments of Coal Deposition. Geological Society of America Special Paper, 114, 143-91.
Heward, A. 1978. Alluvial fan and lacustrine sediments from the Stephanian $A$ and $B$ (La Magdalena, Cin̄era-Matallana and Sabero) coal fields, northern Spain. Sedimentology, 25, 451-88.

IGME 1975. Area lignitifera $y$ uranifera de Mequinenza. Programa de investigación de radioactivos.

- 1985. Prospección previa de lignitos en el area de Pinós-Molsosa (Lérida-Barcelona).

Li Sitian, Li Baofang, Yang Shigong, Huang Jiafu \& Li Zhen. 1984. Sedimentation and tectonic evolution of Late Mesozoic faulted coal basins in north-eastern China. In: RAHMANI, R. \& Flores, R. (eds) Sedimentology of Coal and Coal-bearing sequences. Special Publication of the International Association of Sedimentologists, 7, 387-406.

Malmsheimer, K. \& Mensink, H. 1979. Der geologische Aufbau des Zentralkatalanischen Molassebeckens. Geologische Rundschau, 121-62.

MARTIN, M. 1974. Sobre la petrogénesis de algunas litofacies espan̄olas con fases urano-orgánicas. Boletin Geologico y Minero, 85, 561-81.

Munoz, J., Martinez, J. \& Verges, J. 1986. Thrust sequences in the Spanish Eastern Pyrenees. Journal of Structural Geology, 8, 399-405.

Nurkowski, J. \& RAHMani, R. 1984. An Upper Cretaceous fluvio-lacustrine coal-bearing sequence, Red Deer Area, Alberta, Canada. In: RAHMANI, R. \& Flores, R. (eds) Sedimentology of Coal and Coal-bearing Sequences. Special Publication of the International Association of Sedimentologists, 7, 85-103.

Puigdefabregas, C., Munoz, J. \& Marzo, M. 1986. Thrust belt development in the Eastern Pyrenees and related depositional sequences in the Southern foreland Basin. In: Allen, PH. \& Homewood, P. (eds) Foreland Basins. Special Publication of the International Association of Sedimentologists, 8, 319-36.

Rahmani, R. \& Flores, R. 1984. Sedimentology of Coal and Coal-bearing sequences of North America: a historical review. In: RAHMANI, R. \& Flores, R. (eds) Sedimentology of Coal and Coal-Bearing Sequences. Special Publication of the International Association of Sedimentologists, 7, 3-10.

RIBA, O. 1976. Syntectonic unconformities of the Alto Cardener, Spanish Pyrenees; a genetic interpretation. Sedimentary Geology, 15, 213-33.

Ryder, R., Fouch, T. \& Elison, J. 1976. Early Tertiary sedimentation in the western Uinta Basin, Utah. Geological Society of America Bulletin, 87, 496-512.

SAEZ, A. \& RiBA, O. 1986. Depósitos aluviales y lacustres paleógenos del margen pirenaico catalán de la Cuenca del Ebro. In: ANADON, P. \& CABrera, Ll, (eds) Guía de las Excursiones del XI Congreso Español de Sedimentología, 6, 1-29.

SegureT, M. 1970. Etude tectonique des nappes et séries décollées de la partie centrale du versant sud des Pyrénees. Caractère synsedimentaire, rôle de la compression et de la gravité. Publications de l'Université Scientifique et Technique du Languedoc. Série Géologie Structurale, 2, 161.

Smith, A. \& Briden, J. 1977. Mesozoic and Cenozoic Paleocontinental Maps. Cambridge University Press, Cambridge.

Sole, N. \& PORTA, J. 1982. Contribución a la palinología del Oligoceno en la región de Calaf (Barcelona). Acta Geológica Hispánica, 14, 351-53.

Stach, E., Mackowsky, M., Teichmuller, M., Taylor, G., Chandra, D. \& Teichmuller, R. 1982. Coal Petrology, 3rd edn. Gebruder Bornsträger, Berlin-Stuttgart.

Surdam, R. \& Wolfbauer, C. 1975. Green River Formation Wyoming: a playa-lake complex. Geological Society of America Bulletin, 86, 335-45.

Teichmuller, M. \& Teichmuller, R. 1982. The geological basis of coal formation. In: STach, E., Mackowsky, M. Teichmuller, M., TAYlor, G., Chandra, D. \& Teichmuller. R. (eds) Coal Petrology, 3rd. edn. Gebruder Bornsträger, Berlin-Stuttgart, 381-413.

Wehmeyer, D., Apostolikas, A., Meinke, K., Riegel, W., Schwarz, G. \& VELITZELOS, E. 1986. Environments of coal formation and sedimentary framework of Miocene lignites from Aliveri (Evia, Greece). Abstracts of the International Symposium on Coal and Coal-Bearing Strata. Royal Holloway and Bedford New College (University of London), 55.

Whateley, 1986. Lignite-bearing lacustrine deposits (Miocene) in the Soma-Isilkar Basin, Eastern Turkey. Abstracts of the International Symposium on Coal and Coal-Bearing strata. Royal Holloway and Bedford New College (University of London), 56. 